\title{
Prevalence of Paramphistomum infection in cattle and sheep in Van Province, Turkey
}

\author{
N. OZDAL ${ }^{1 *}$, A. GUL ${ }^{1}$, F. ILHAN ${ }^{2}$, S. DEGER ${ }^{1}$
}

\begin{abstract}
${ }^{1}$ Department of Parasitology, Faculty of Veterinary Medicine, University of Yuzuncu Y1l, Van, 65080, Turkey, E-mail:nalan.ozdal@hotmail.com,agul68@hotmail.com,serdardeger61@yahoo.com; ${ }^{2}$ Department of Pathology, Faculty of Veterinary Medicine, University of Yuzuncu Y11, Van, 65080, Turkey, E-mail: fatmasayn@hotmail.com
\end{abstract}

\begin{abstract}
Summary
This study was carried out in naturally infected cattle and sheep from May, 2006 to April 2007 in Van province, in the eastern of Turkey, to assess the prevalence of paramphistomosis. The rumen and reticulum of slaughtered cattle and sheep were collected monthly from abattoirs (Van Municipality of Slaughterhouse) to monitor the seasonal occurrence of paramphistomosis. 447 cattle and 948 sheep were examined, out of which 8.95 and $4.43 \%$ were positive for Paramphistomum infection, with the mean intensity \pm standard error of mean of $97.55 \pm 12.50$ and $89.17 \pm 13.02$, respectively. The highest infection in the cattle and sheep infected with Paramphistomum spp. was found during the autumn (September to November) (14.10 $\%, 8.33 \%$ ) and fallowed by the summer seasons (June to August) $(9.02 \%, 5.18 \%)$.
\end{abstract}

Key words: Paramphistomosis; seasonal prevalence; cattle; sheep; pathology; Van

\section{Introduction}

Paramphistomosis caused by digenetic flukes belonging to the superfamily Paramphistomoidea is distributed all around the world, but its highest prevalence has been reported in tropical and subtropical regions, particularly in Africa, Asia, Australia, Eastern Europe and Russia (Boray, 1959, 1969; Horak, 1971; Gupta et al., 1978). It has been reported that paramphistomosis is caused by specific species of the parasite depending on the regions. For instance, in Europe, Paramphistomum cervi has been reported in Russia, Bulgaria, Poland, France, and Italy; while Paramphistomum microbothrium has been reported from Sardinia, Yugoslavia, and Hungary (Horak, 1971). In Australia and New Zealand, species of paramphistomes affecting cattle and sheep are Paramphistomum ichikawai and Calicophoron calicophorum (Brotowidjoyo \& Copeman, 1979). In Asia, P. cervi, Paramphistomum explanatum,
Gastrothylax crumenifer, Cotylophoron cotylophorum, Fischoederius elongatus, and Fischoederius cobboldi have been recorded in India, Ceylon and China (Boray, 1959; Malek, 1980; Hanna et al., 1988; Wang et al., 2006). Species responsible for infection in Turkey are mainly to P.cervi, later P. ichikawai and Calicophoron daubneyi (Coskun 1988a; 1988b; Tinar et al., 1992).

Adult paramphistomes are the main parasites in the rumen and reticulum of sheep, goats, cattle and water buffaloes. Their early stages are in small intestine and then migrate through the abomasum towards the rumen (Sanabria \& Romero, 2008). The harm caused by this infection in bovine affects production, since these parasites provoke a lower nutritious conversion, a loss of weight and/or a decrease in milk production, which cause economic losses. In some areas of India, the Republic of South Africa and Australia, the mortality of cattle has reached 80 or $90 \%$ in sheep and cattle (Boray, 1959; Soulsby, 1987). In Europe, the presence of adult paramphistomes was previously regarded to be relatively harmless in cattle. However, recent reports demonstrated that Paramphistome species present in Europe (Paramphistomum daubneyi most frequently) can cause significant gastrointestinal disease; drop in production or even death (Dorchies et al., 2002).

Van province is located at the $42^{\circ} 40^{\prime} \mathrm{E}$ and $44^{\circ} 30^{\prime} \mathrm{E}$ longitude and $37^{\circ} 43^{\prime} \mathrm{N}$ and $39^{\circ} 26^{\prime} \mathrm{N}$ latitude. This region is at an altitude of approximately 1.725 meters and has close borders to Iran eastern. Van province has change over type climate between terrestrial and Mediterranean climate of Central Anatolia and Southeast Anatolia regions. Cause of this climate change is Van Lake. On the basis of temperature and precipitation, four seasons in a year recognized in Van (Eastern Turkey) are: winter (December to February); spring (March to May); summer (June to August); autumn (September to November).

The present study was designed to report the seasonal and overall prevalence of the paramphistomes in cattle and 
sheep in Van province. Moreover, it was included the intensity and ruminal damage of infestation by evaluating of the ruminal histological samples and counting collected parasites.

\section{Material and Methods}

This study was carried out in sheep and cattle from May, 2006 to April 2007 in Van province, in the eastern of Turkey. A total of 447 cattle and 948 sheep were examined over this the period. Van Municipality of Slaughterhouse was visited regularly in every month. The rumen and reticulum of slaughtered cattle and sheep were collected monthly from abattoirs to determine the seasonal prevalence of parasite and were checked for the presence of adult flukes. Parasites collected from each animal were counted to determine intensity of infections. All examined sheep and cattle belonged to Van breeds.

Furthermore, the samples from rumen of 20 cattle infected adult Paramphistomum spp., were taken and fixed in $10 \%$ neutralized formaldehyde. The fixed samples were embedded in paraffin wax, sectioned at $4-5 \mu \mathrm{m}$, and stained with hematoxylin and eosin (HE) for histopathologic examination. The prepared sections were examined under light microscope.

Using the obtained data, the infection was estimated: prevalence $(\%)$ and mean intensity (total number of individuals of a particular parasite species in a sample of a host species/ number of infected individuals of the host species in the sample) (Margolis et al., 1982). Chi-square test was employed to measure association between the parasitism and season. The data was analyzed using SPSS-11.5 for Windows (evaluation version). In all the analyses, confidence level was held at $95 \%$ and $\mathrm{P}<0.05, \mathrm{P}<0.01$ and $\mathrm{P}<0.001$ for significance.

\section{Results}

During the one year study period from May, 2006 to April 2007 a total of 447 cattle and 948 sheep at slaughter houses were examined for paramphistomosis, 40 (8.95\%) and 42 $(4.43 \%)$ were found positive for paramphistomum infec-
Table 1. Seasonal prevalence of paramphistomosis in cattle and sheep in Van according to gut examination

$$
\text { Cattle Sheep }
$$

\begin{tabular}{ccccc} 
Season & Examined & $\begin{array}{c}\text { Infected } \\
(\%)\end{array}$ & Examined & $\begin{array}{c}\text { Infected } \\
(\%)\end{array}$ \\
\hline Spring & 121 & $8(6.61)$ & 235 & $7(2.98)$ \\
Summer & 133 & $12(9.02)$ & 193 & $10(5.18)$ \\
Autumn & 78 & 11 & 264 & $22(8.33)$ \\
& & $(14.10)$ & & \\
Winter & 115 & $9(7.83)$ & 256 & $3(1.17)$ \\
\hline Total & 447 & $40(8.95)$ & 948 & $42(4.43)$ \\
\hline Cattle: $\mathrm{P}=0.31$, Sheep: $\mathrm{P}<0.001$ &
\end{tabular}

Cattle: $\mathrm{P}=0.31$, Sheep: $\mathrm{P}<0.001$

tion as to gut examination, with the mean intensity \pm standard error of mean of $97.55 \pm 12.50$ and $89.17 \pm 13.02$, respectively (Table 1). While all of the parasites in cattle were present at rumen, Paramphistomum spp. was found at both rumen and reticulum in only two sheep.

Seasonal prevalence of paramphistomosis in cattle and sheep are given Table 1. When each season was considered, highest incidence of paramphistomosis in sheep was during Autumn (September to November) with the prevalence rate of $8.33 \%$ followed by $5.18 \%$ in Summer (June to August), $2.98 \%$ in Spring (March to May), 1.17 in Winter (December to February) (chi-square or likelihood ratio: $\mathrm{P}<0.001$ ) and, in cattle, highest prevalences, although non significant (chi-square: $\mathrm{P}=0.31$ ), were recorded $14.10 \%$ in Autumn, followed by $9.02 \%$ in Summer, $7.83 \%$ in Winter and $6.61 \%$ in Spring.

Figure 1 gives the seasonal variations in the monthly prevalences of these natural infections in cattle and sheep according to gut examination. The highest positive examinations was recorded from July to November with the prevalence rate of $10.42 \%$ in July, $10.53 \%$ in August, $15 \%$ in September, $12.5 \%$ October, $14.71 \%$ in November in cattle $(\mathrm{P}>0.05)$ and $5.62 \%$ in July, $7.02 \%$ in August, $4.88 \%$ in September, $5.68 \%$ October, $11.11 \%$ in November in sheep $(\mathrm{P}<0.001)$. The lowest prevalences of paramphistomosis

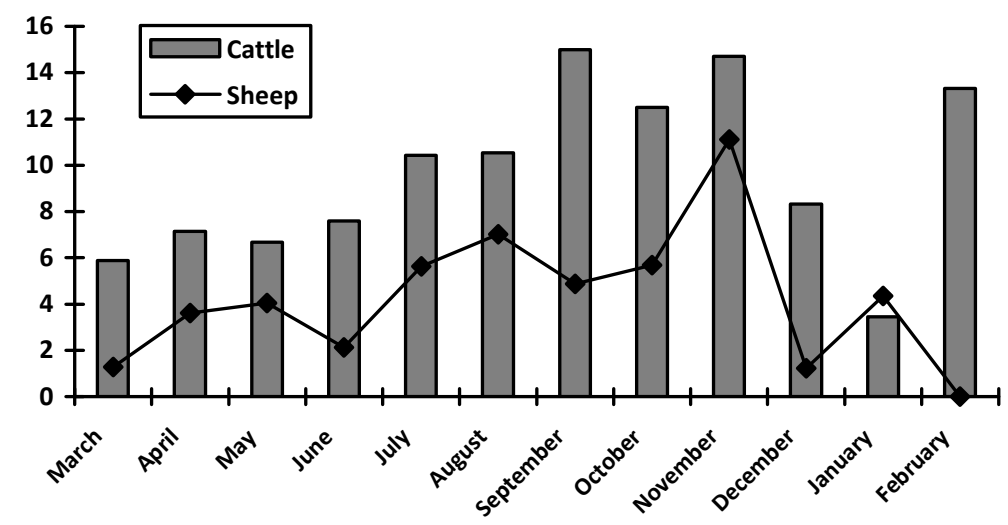

Fig. 1. Monthly prevalence of Paramphistomum spp. according to gut examination in cattle and sheep in Van province. Cattle: $\mathrm{P}>0.05$, Sheep: $\mathrm{P}<0.001$ 
were noted $3.45 \%$ in January, $5.88 \%$ in March and $6.67 \%$ in May in cattle $(\mathrm{P}>0.05)$. In sheep, the lowest prevalences rate was $0 \%, 1.23 \%$ and $1.28 \%$ in February, December and March $(\mathrm{P}<0.001)$, respectively (Fig. 1).

Macroscopically and microscopically, it was show that many parasites attached to the ruminal papillae. Microscopically, there was mild to moderate severity infiltration of mononuclear cells, and occasionally, few eosinophils in lamina propria and hydropic degeneration in lamina epithelialis of the rumen. Detaching Paramphistomum species from the ruminal papilla revealed an atrophic (Fig. 2). coprological analysis, $15 \%$ in Southern Marmara Region (Tinar et al., 1992), and $13.6 \%$ in Afyon Province (Kircali Sevimli et al., 2005) by postmortem examination in cattle. In this study, prevalence of paramphistomosis in sheep was on yearly average at $4.43 \%$ and on throughout the year with between $0 \%$ and $11.11 \%$, which is much lesser than that recorded in Heilongjiang Province in People's Republic of China (Wang et al., 2006; $48.8 \%$ ), in Maiduguri in Nigeria (Biu \& Oluwafunmilayo, 2004; $28.0 \%$ ), but is similar in Himalayan region of India (Tariq et al., 2008; $7.3 \%)$ and to that found in the Fars province of Iran (Moghaddar and Khanitapeh, 2003; $1.66 \%$ ).

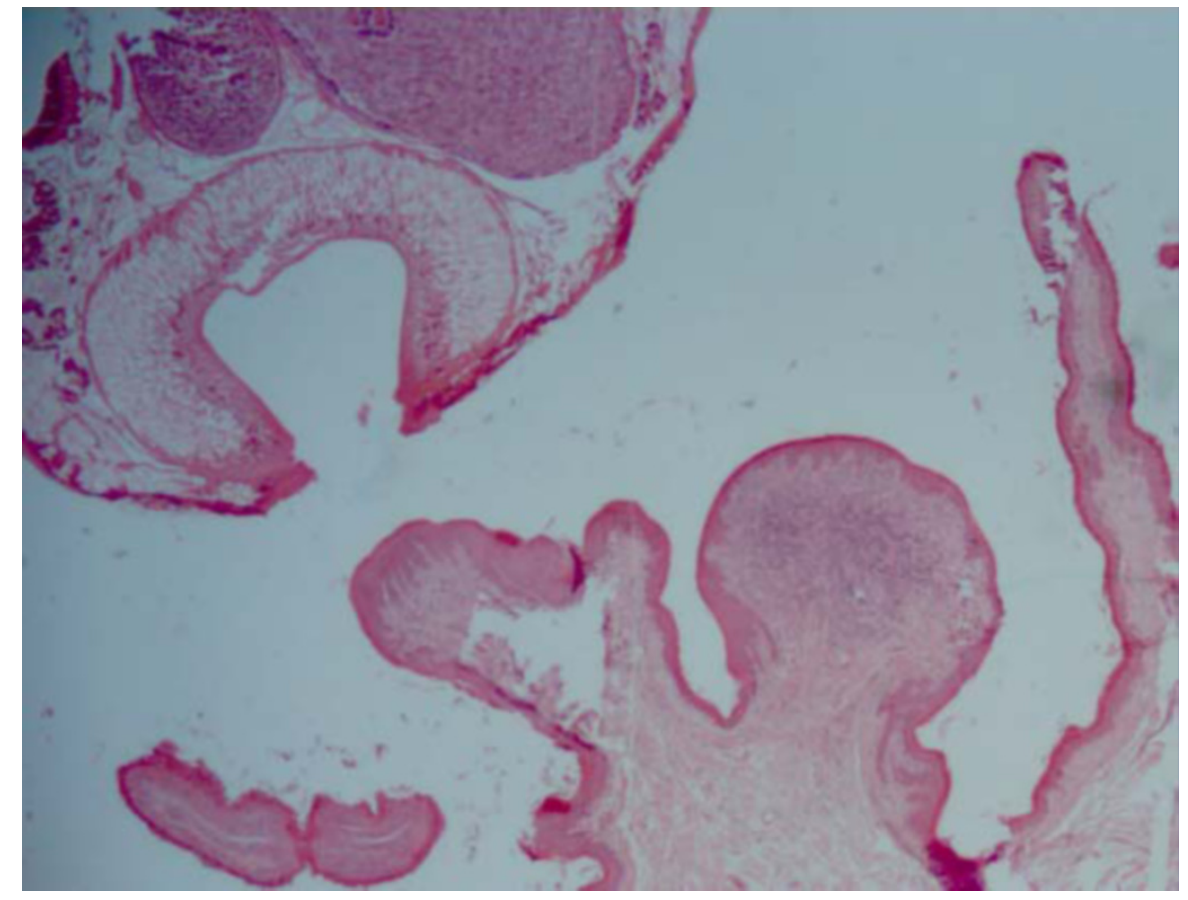

Fig. 2. Paramphistomum spp. was attached to the ruminal papillae. HE, x 25

\section{Discussion}

Prevalence and species caused paramphistomosis show a variation according to countries in the different geographical regions of the world and animal kind. In present study, paramphistomosis in cattle was found throughout the year with prevalence between $3.45 \%$ and $15 \%$, and with a yearly average of $8.95 \%$. Rangel-Ruiz et al. (2003) from Tabasco reported prevalence of $P$. cervi as $39.10 \%$ in cattle. It is reported that prevalence of paramphistomosis in cattle in France ranged from $5.2 \%$ to $44.7 \%$ (Mage et al., 2002; Szmidt-Adjidéa et al., 2000). Padungtoda et al. (2001) reported $40 \%$ prevalence of Paramphistomum spp. in dairy cattle from Chiang Mai province of the northern region of Thailand. According to coprological analysis, the prevalence rates of $34 \%$ and $29.5 \%$ were detected in cattle in Portneuf County (Quebec) and Zimbabwe, respectively (Bouvry \& Rau, 1984; Pfukenyi et al., 2005). This infection in Turkey is partially reported, with prevalences ranging from $33 \%$ in Ordu, to $17 \%$ in Samsun (Celep, 1984), $14.5 \%$ in Kayseri (Y1ldırım et al., 2000) by
It is reported that prevalence of paramphistomosis in sheep in different province of Turkey ranged from $0.5 \%$ to $100 \%$ and the highest and lowest rate were found in Eskisehir and Kars, respectively (Coskun, 1988; Tinar et al., 1992; Guralp, 1981; Gicık et al., 2003). Comparing our prevalence results with those recorded in other province of Turkey, the current infection figures are similar in Çankırı, Antalya, Kırşehir and to that stated in South Marmara Region (Coskun, 1988; Tinar et al., 1992). This might result from actual differences due to different environments.

The highest prevalence of Paramphistomum spp. in sheep and cattle in the autumns and summer season is in agreement with the observations of other workers. Rangel-Ruiz et al. (2003) from Tabasco, Mexico reported cattle were infected mainly throughout the rainy and windy seasons, during summer, autumn and at the beginning of winter. Tariq et al. (2008) reported highest infection in sheep in summer and lowest in winter, in the North West temperate Himalayan region of India and in the same study was reported the intensity and severity of infection reaches to its maximum in late summer and autumn season the drier 
months. They also emphasize that the low prevalence in winter could be attributed to harsh snowy winter conditions during which the whole valley remains snow covered and there are no chances of fresh infection due to nonavailability of intermediate snail hosts (Tariq et al., 2008). According to Soulsby (1982) the out breaks of paramphistomosis generally occur in drier months. The lowest prevalence in winter (November to December) with the prevalence rate of $0.49 \%$ and highest prevalence during monsoon and post-monsoon (July to October) (8.06\%) followed by in summer (March to June) $(2.92 \%$ ) were also well documented in domestic ruminants by Hassan et al. (2005). It was reported that peak fluke burdens and clinical paramphistomosis occurred in late summer and early winter in calves in a subtropical location in eastern Australia (Rolfe et al., 1991).

In general, the results of this study are in accordance to those presented for other tropical and subtropical regions of the world in which the highest infection was reported in summer time, autumn and at the beginning of winter (Kamburov, 1977). Nevertheless, in other latitudes, some differences were observed. For instance, in France, the prevalence of $P$. daubneyi, decreased in July and August and increased from September to January (Mage et al., 2002) whilst in Chattisgarh State in India they decreased summer and increased during postmonsoon season (Galdhar \& Roy, 2005).

Pathogenic effect of paramphistomosis depends on the number of parasites in the animals. In experimental paramphistomosis induced with $P$. ichikawai in lambs, it was observed severe destruction that associated with increased infiltration with eosinophils in the mucosa of the rumen. In the same study, it is suggested that the presence of 20,000 to 25,000 flukes would result in clinical disease; smaller numbers would cause significant subclinical disease (Rolfe et al., 1994). Most infections of adult fluke are harmless although large numbers of fluke can cause a chronic ulcerative rumenitis with atrophy of ruminal papillae (Love $\&$ Hutchinson, 2003). The immature forms of P. cervi caused more severe damage in the duodenal tissue, whereas the adult form inflicted mild tissue damage in the rumen of the experimental kids (Singh et al., 1994). In this study, severity of rumen lesions was also defined as mild. This may be to result from small number of parasites sucking the rumen mucosa into the acetabulum compared as compared with that recorded in the study of Rolfe et al. (1994). In order to take measures of control and determine precisely seasonal prevalence for paramphistomosis in this geographical region, further studies that include several years of works in animals bred in Van region, both gut and faecal examination, infections caused by immature forms, and also determination of infection in the intermediate host snails should be made.

\section{Acknowledgments}

The authors gratefully acknowledge Memis Bolacalı's support with the statistical calculations.

\section{References}

BiU A. A., OluWAFunMilayo A. (2004): Identification of some Paramphistomes infecting sheep in Maiduguri, Nigeria Pakistan Vet. J., 24(4): 187 - 189

BORAY, J. C. (1959): Studies on intestinal amphistomosis in cattle. Aust. Vet. J., 35: 282 - 287. DOI: 10.1111/j.17510813.1959.tb08480.x

BORAY, J. C. (1969): The anthelmintic efficiency of niclosamide and menichlopholan in the treatment of intestinal paramphistomosis in sheep. Aust. Vet. J., 45: 133 134. DOI: 10.1111/j.1751-0813.1969.tb01905.x

Bouvry, M., RAU, M. E. (1984): Paramphistomum spp. in dairy cattle in Quebec. Can. Vet. J., 25: $353-356$

Brotowidjoyo, M. D., Copeman, D. B. (1979): Abattoir survey of bovine paramphistomiasis in North Queensland. Aust. Vet. J., 55: 402. DOI: 10.1111/j.1751-0813.1979.tb15879.x

CELEP, A. (1984): Findings of helmintological and periferal blood smear examinations according to faeces examination in cattle in Samsun, Ordu and their provinces.

Etlik. Vet. Mikrob. Derg., 5(6-7): $106-112$

Coskun, S. Z. (1988): The prevalence of Paramphistomum spp. in ruminants. Doga Turk. Vet. Hay. Derg., 12(3): 168 $-179$

Dorchies, P., Lacroux, C., Navetat, H., Rizet, C., Gueneau, E., Bisson, B., Ferte, H. (2002): Trois cas d'une nouvelle entité pathologique: la paramphistomose larvaire chez les bovins. Bull. GTV, 13: 91-93

GALDHAR, C. N., RoY, S. (2005): Studies on prevalence of bovine paramphistomiasis in Chhattisgarh State. Indian Vet. J., 82(9): 938 - 940

GiciK, Y., Arslan, M. O., Kara, M., Kose, M. (2003): The prevalence of Paramphistomiasis in sheep slaughtered in the Kars province. T. Parazitol. Derg., 27(4): $260-261$ GuPTA, P. P., SingH, B., DuTT, S. C. (1978): A note on amphistomiasis in an adult buffalo. Indian Vet. J., 55: $491-492$ Guralp, N. (1981): Helmintolji. 2. Bask1, Ankara Univ. Basımevi, Ankara. 631 pp.

Hanna, R. E. B., Williamson, D. S., Mattison, R. G., NizAMI, W. A. (1988): Seasonal reproduction in Paramphistomum epiclitum and Gastrothylax crumenifer, rumen paramphistomes of the indian water buffalo, and comparison with the biliary paramphistome Gigantocotyle explanatum. Int. J. Parasitol., 18: 513 - 521. DOI: 10.1016/00 20-7519(88)90016-1

Hassan, S. S., Kaur, K., Joshi, K., JuYaL, P. D. (2005): Epidemiology of paramphistomosis in domestic ruminants in different districts of Punjab and other adjoining areas. $J$. Vet. Parasitol., 19(1): 43 - 46

HoRAK, I. G. (1971): Paramphistomiasis of domestic ruminants. Adv. Parasitol., 9: 33 - 71. DOI: 10.1016/S0065308X(08)60159-1

KAMBUROV, P. (1977): Establishment of Paramphistomum microbothrioides (Price. McIntosth, 1944) in Bulgaria. Sofia Helminthol. 4, $22-28$

Kircali Sevimli F, Kose M., Kozan E., Dogan N. (2005): Paramphistomiasis and Distomatosis in Cattle in the Afyon Province. T. Parazitol. Derg., 29(1): 43 - 46 
Love, S. C. J., Hutchinson, G. W. (2003): Pathology and diagnosis of internal parasites in ruminants. In Gross $\mathrm{Pa}$ thology of Ruminants, Proceedings 350, Post Graduate Foundation in Veterinary Science, University of Sydney, Sydney; Chapter 16: 309-338. Retrieved March, 2006. http://www.dpi.nsw.gov.au/_data/assets/pdf_file/0003/34 608/lh-pathol-int-para.pdf

Mage, C., Bourgne, H., Toullieu, J. M., Rondelaud, D., Dreyfuss, G. (2002): Fasciola hepatica and Paramphistomum daubneyi: changes in prevalences of natural infections in cattle and in Lymnaea truncatula from central France over the past 12 years. Vet. Res., 33: $439-447$. DOI: $10.1051 /$ vetres:2002030

MaleK, E. A. (1980): Snail-Transmitted Parasitic Diseases. CRC Press Inc., Florida, pp. 199-220.

Margolis, L., Esch, G. W., Holmes, J. C., Kuris, A. M., SCHAD, G. A. (1982): The use of ecological terms in parasitology (Report of an ad hoc committee of the American Society of Parasitologists). J. Parasitol., 68: 13 1-133

Moghaddar, N., Khanitapeh, N. (2003): Prevalence of paramphistomes in sheep and goat in the Fars province of Iran. Iran J. Vet. Res., 4(2): 166 - 170

Padungtoda, P., Kaneene, J. B., Jarman, D., Jones, K., Johnson, R., Drummond, A., Duprey, Z., ChaichanAPUNPOL I. (2001): Enteric parasitosis in northern Thailand dairy heifers and heifer calves. Prev. Vet. Med., 48: $25-$ 33. DOI: 10.1016/S0167-5877(00)00179-3

Pfukenyi, D. M., Mukaratirwa, S., Willingham, A. L., MONRAD, J. (2005): Epidemiological studies of amphistome infections in cattle in the Highveld and Lowveld communal grazing areas of Zimbabwe. Onderstepoort $J$. Vet. Res., 72(1): $67-86$

Rangel-Ruiz, L. J., Albores-Brahms, S. T., GamboAAguilar, J. (2003): Seasonal trends of Paramphistomum cevri in Tabasco, Mexico. Vet. Parasitol., 116: 217 - 222. DOI: 10.1016/j.vetpar.2003.07.002

Rolfe, P. F., Boray, J. C., Nichols, P., Collins, G. H. (1991): Epidemiology of paramphistomosis in cattle. Int. J.
Parasitol., 21: 813 - 819. DOI: 10.1016/0020-7519(91) 90150-6

Rolfe, P. F., Boray, J. C., Collins, G. H. (1994): Pathology of infection with Paramphistomum ichikawai in sheep. Int. J. Parasitol., 24 (7): 995 - 1004. DOI: 10.1016/ 0020-7519(94)90165-1

SANABria, R. E. F., Romero J. R. (2008): Review and update of paramphistomosis Helminthologia, 45 (2): 64 68. DOI: $10.2478 / \mathrm{s} 11687-008-0012-5$

SinGH, R. P., SAHAI, B. N., JHA, G. J. (1984): Histopathology of the duodenum and rumen of goats during experimental infections with Paramphistomum cervi. Vet. Parasitol., 15(1): 39 - 46. DOI: 10.1016/0304-4017(84)90108-0

Soulsby, E. J. L. (1986): Helminths, Arthropods and Protozoa of Domesticated Animals. $7^{\text {th }}$ ed., Baillere Tindall, London.

SzMidT-AdjidÉA, V., ABrous, M., AdjidÉ, C. C., Dreyfuss, G., LeCompte, A., CABARET, J., Rondelaud, D. (2000): Prevalence of Paramphistomum daubneyi infection in cattle in central France. Vet. Parasitol., 87: 133 138. DOI: 10.1016/S0304-4017(99)00168-5

Tariq, K. A., Chishti, M. Z., Ahmad, F., Shawl, A. S. (2008): The epidemiology of paramphistomosis of sheep (Ovis aries L.) in the North West temperate Himalayan region of India. Vet. Res. Commun., 32: 383 - 391. DOI: 10.1007/s11259-008-9046-X

Tinar, R., Coskun, S. Z., Dogan, H., Demir, S., Akyol, Ç. V. (1992): The prevalence of Amphistomum spp. in ruminants of South Marmara region. Turk. J. Vet. Anim. Sci., 16: $187-197$

WANG, C. R., QIU, J. H., ZHU, X. Q., HAN, X. H., NI, H. B., ZhaO, J. P., ZhOU, Q. M., ZhanG, H. W., Lun, Z. R. (2006): Survey of helminthes in adult sheep in Heilongjiang Province, People's Republic of China. Vet. Parasitol., 140: 378 - 382. DOI: 10.1016/j.vetpar.2006.04.008

YILDIRIM, A., KARA, M., KoZAN, E., OGE, H. (2000): The prevalence of helminth infections in cattle raised in barns in Kayseri province. Ankara Univ. Vet. Fak. Derg., 47: 333 - 337 